\title{
Commentary: The search for the Holy Grail to prevent anastomotic leaks: Let's keep looking, it is not omentoplasty
}

\author{
D. Aaron Guel, MD, and Benny Weksler, MD
}

\footnotetext{
From the Division of Thoracic and Esophageal Surgery, Department of Thoracic and Cardiovascular Surgery, Allegheny General Hospital, Pittsburgh, Pa.

Disclosures: B.W. is a proctor for Intuitive Surgery and speaker for AstraZeneca.

Received for publication Oct 11, 2019; revisions received Oct 11, 2019; accepted for publication Oct 15, 2019; available ahead of print Jan 8,2020

Address for reprints: Benny Weksler, MD, Division of Thoracic and Esophageal Surgery, Department of Thoracic and Cardiovascular Surgery, 320 E. North Ave, 14th Fl, South Tower, Pittsburgh, PA 15212 (E-mail: benny. weksler@ahn.org).

J Thorac Cardiovasc Surg 2020;159:2106-7

$0022-5223 / \$ 36.00$

Copyright (c) 2019 by The American Association for Thoracic Surgery

https://doi.org/10.1016/j.jtcvs.2019.10.062
}

In 2015, the number of minimally invasive esophagectomies performed in the United States surpassed the number of open esophagectomies performed. ${ }^{1}$ Minimally invasive esophagectomy is associated with decreased postoperative morbidity, mostly by reducing pulmonary complications, and improved quality of life. ${ }^{2,3}$ However, despite recent advances, esophagectomy is still a morbid procedure. Morbidities occur in $>60 \%$ of patients, and mortality is $3.8 \%{ }^{4}$ Anastomotic leaks are one of the most dangerous complications of esophagectomy and continue to vex surgeons. Leaks occur in at least $10 \%$ of patients, and $10 \%$ to $15 \%$ of these patients die in the postoperative period. ${ }^{4,5}$ In addition to the emotional toll on patients, families, and surgeons, the management of an anastomotic leak can pose a tremendous cost burden, increasing hospital stay by a week and doubling the cost of the esophagectomy.

Many surgeons use an omental flap, wrapped around the anastomosis, to attempt to decrease the incidence of leaks. Three randomized trials showed a decreased incidence of anastomotic leak with the use of omentum..$^{7-9}$ These studies included both transthoracic and transhiatal esophagectomies, preceded the era of minimally invasive surgery, and were done in patients with squamous cell cancer. Curiously, a metanalysis of the 3 randomized studies ${ }^{10}$ showed that only patients who underwent transhiatal esophagectomy benefitted from an omental flap; no benefit was seen in patients who received omentoplasty during transthoracic esophagectomy.

In the current issue of the Journal, Lu and colleagues ${ }^{11}$ from the University of Pittsburgh explored the value of wrapping the anastomosis with an omental flap in a retrospective series of patients with esophageal cancer who underwent minimally invasive Ivor Lewis esophagectomy after neoadjuvant chemoradiation. The study population is different from the previous randomized studies and is more contemporary and in line with current practice
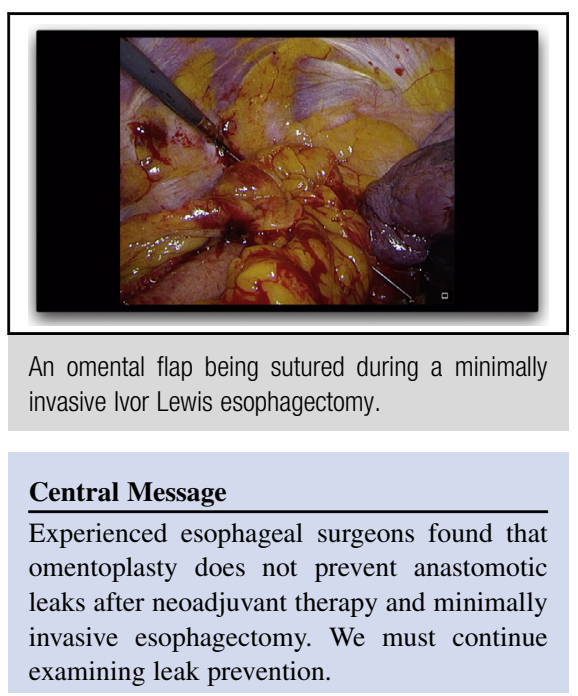

See Article page 2096.

guidelines recommending neoadjuvant therapy for patients with esophageal cancer. The authors identified 245 patients who had neoadjuvant chemoradiotherapy followed by minimally invasive Ivor Lewis esophagectomy. Approximately $60 \%$ of patients $(147 / 245)$ had omentoplasty. It is important to note that most of the esophagectomies $(71.8 \%, 176 / 245)$ were performed by Dr Luketich, arguably the surgeon with the most experience with minimally invasive esophagectomy in the United States. Applying advanced statistics and careful propensity matching, the authors were unable to demonstrate a therapeutic benefit of adding an omental flap to their anastomosis. This is concordant with the meta-analysis of previous studies that showed no benefit of an omental flap during transthoracic esophagectomy.

There are other important points in the study that should serve as examples to all of us publishing the results of esophagectomy. The incidence of anastomotic leak was carefully reported and appropriately classified. In the best hands of the group with the largest published experience in minimally invasive Ivor Lewis esophagectomy, the leak rate was $15 \%$. Most of the leaks required some intervention, and only 4 of 37 patients $(10.8 \%)$ had Class 1 leaks, which were detected radiographically but did not require intervention. The need to take down the newly constructed conduit due to tip necrosis (Class 4 leak) occurred in $\sim 8 \%$ of patients with leaks (3/37) and in 1.2\% (3/245) of all patients. 
These are sobering results, and I commend the authors for their transparency.

As a surgeon who uses omental flaps in my esophageal anastomosis, the results are disappointing. Over the years, I have witnessed small leaks in patients with omental flaps, and some class 4 leaks, but I had the impression that free leaks occurred less often with the flaps. This impression is not supported by the data presented by $\mathrm{Lu}$ and colleagues. So, the big question is, where do we go from here? For those of us who use omental flaps, should we stop doing them? What can surgeons do to prevent anastomotic leaks? We will need to continue to search for the Holy Grail to prevent anastomotic leaks, but we should not accept leaks in more than $10 \%$ of patients undergoing esophagectomy as inevitable.

\section{References}

1. Espinoza-Mercado F, Imai TA, Borgella JD, Sarkissian A, Serna-Gallegos D, Alban RF, et al. Does the approach matter? Comparing survival in robotic, minimally invasive, and open esophagectomies. Ann Thorac Surg. 2019;107:378-85.

2. Biere SS, van Berge Henegouwen MI, Maas KW, Bonavina L, Rosman C, Garcia JR, et al. Minimally invasive versus open oesophagectomy for patients with oesophageal cancer: a multicentre, open-label, randomised controlled trial. Lancet. 2012;379:1887-92.
3. Mariette C, Markar SR, Dabakuyo-Yonli TS, Meunier B, Pezet D, Collet D, et al. Hybrid minimally invasive esophagectomy for esophageal cancer. $N$ Engl J Med. 2019;380:152-62.

4. Sihag S, Kosinski AS, Gaissert HA, Wright CD, Schipper PH. Minimally invasive versus open esophagectomy for esophageal cancer: a comparison of early surgical outcomes from the Society of Thoracic Surgeons National Database. Ann Thorac Surg. 2016;101:1281-8; discussion 1288-9.

5. Kassis ES, Kosinski AS, Ross P Jr, Koppes KE, Donahue JM, Daniel VC. Predictors of anastomotic leak after esophagectomy: an analysis of the society of thoracic surgeons general thoracic database. Ann Thorac Surg. 2013; 96:1919-26.

6. Agzarian J, Visscher SL, Knight AW, Allen MS, Cassivi SD, Nichols FC III, et al. The cost burden of clinically significant esophageal anastomotic leaks-a steep price to pay. J Thorac Cardiovasc Surg. 2019;157:2086-92.

7. Bhat MA, Dar MA, Lone GN, Dar AM. Use of pedicled omentum in esophago gastric anastomosis for prevention of anastomotic leak. Ann Thorac Surg. 2006; $82: 1857-62$

8. Dai JG, Zhang ZY, Min JX, Huang XB, Wang JS. Wrapping of the omental pedicle flap around esophagogastric anastomosis after esophagectomy for esophageal cancer. Surgery. 2011;149:404-10.

9. Zheng QF, Wang JJ, Ying MG, Liu SY. Omentoplasty in preventing anastomotic leakage of oesophagogastrostomy following radical oesophagectomy with three-field lymphadenectomy. Eur J Cardiothorac Surg. 2013; 43:274-8.

10. Yuan Y, Zeng X, Hu Y, Xie T, Zhao Y. Omentoplasty for oesophagogastrostomy after oesophagectomy. Cochrane Database Syst Rev. 2014:CD008446.

11. Lu M, Luketich JD, Levy RM, Awais O, Sarkaria I, Visintainer P, et al Anastomotic complications after esophagectomy: impact of omentoplasty in propensity-weighted cohorts. J Thorac Cardiovasc Surg. 2020;159:2096-105. 